Research article

\title{
Assessing micronutrient management and fertilizer doses on soil and foliar properties and yield in Dashehari mango grown orchard soils of subtropical region
}

\author{
Tarun Adak*, Kailash Kumar and Vinod Kumar Singh \\ Division of Crop Production, Central Institute for Subtropical Horticulture, Rehmankhera, \\ Lucknow-226101, Uttar Pradesh, India
}

*Corresponding Author: tarunadak@gmail.com

[Accepted: 12 November 2019]

\begin{abstract}
Fertilizer management for enhancing fruit yield of mango is needed in orchards of Lucknow region for better livelihood security of mango growers. Micronutrients and fertilizer doses were impacting on soil properties, leaf tissue nutrient contents as well as yield as evidenced from the field experiment. A range of 9.08 to $12.74 \mathrm{t} \mathrm{ha}^{-1}$ mango cv. Dashehari was recorded. Soil properties were impacted and varied across surface and sub-surface soil depths. The highest and lowest content of $\mathrm{Mn}, \mathrm{Fe}, \mathrm{Cu}$ and $\mathrm{Zn}$ was recorded as 24.60, 13.30, 2.07 and $9.71 \mathrm{mg} \mathrm{kg}^{-1}$ in surface soils and 11.04, 5.67, 0.58 and $2.16 \mathrm{mg} \mathrm{kg}^{-1}$ in sub-surface soils across treatments respectively. Soil organic carbon, $\mathrm{P}$ and $\mathrm{K}$ contents in surface soil had 0.55\%, 20.48 and 196.46 $\mathrm{mg} \mathrm{kg}^{-1}$ while sub-surface soils had $0.25 \%, 11.602$ and $135.0 \mathrm{mg} \mathrm{kg}^{-1}$ respectively. Higher foliar nutrient content of $\mathrm{N}, \mathrm{P}$ and $\mathrm{K}$ was recorded as $1.97,0.121$ and $1.25 \%$ while that of micronutrients 210.75, 87.92, 31.83 and $28.92 \mathrm{mg} \mathrm{kg}^{-1} \mathrm{Fe}, \mathrm{Mn}, \mathrm{Cu}$ and $\mathrm{Zn}$ respectively. Inclusion of micronutrients + NPK + FYM or replacing the doses of NPK by half and inclusion of micronutrients + biofertilizer/green manuring may sustain the mango productivity of this region.
\end{abstract}

Keywords: Mango - Soil depths - Nutrient variations - Foliar content - Yield.

[Cite as: Adak T, Kumar K \& Singh VK (2019) Assessing micronutrient management and fertilizer doses on soil and foliar properties and yield in Dashehari mango grown orchard soils of subtropical region. Tropical Plant Research 6(3): 417-423]

\section{INTRODUCTION}

Farmers of Malihabad, Lucknow region are engaged in fruit production for which fertilizer management is one of the key components for improving the quality mango fruit (Adak et al. 2019). The doses and types of nutrient sources also impact on the products as well as on the orchard soils. Sometimes micronutrients application and inclusion of biofertilizers in the nutrient schedule may supply the exact nutrient required for optimum growth and development of the fruit. Green manuring in the orchard is also another option for improving the soil organic matter content as well as nutrient supply (Kumar et al. 2017). The reduction in doses of chemical fertilizer and its judicious adjustment with other organic sources may save the input cost of farmers and thereby lowering the cost of cultivation. Spraying of micronutrients on tree foliage also supports the nutrient supply chain as after harvesting, tree gets exhausted and devoid of required mineral content. Further, micronutrient applications may perform better in supplying the nutrients during the fruit developmental stages. Soil properties are deeply impacted by the differential input application. Both surface and sub-surface soil could have impacted and variable content of nutrient amounts as a function of soil nutrient management system gets recorded. This variation over the fruiting season is the direct or indirect contribution added by the soil applied nutrients. The reserve nutrient could influence to the nutrient releasing pattern on long-term basis to tree roots. The purpose of this study was to evaluate the effect of micronutrients, biosources and doses of fertilizer on Dashehari mango under subtropical condition.

\section{MATERIALS AND METHODS}

Field experiment was laid out in the experimental farm of ICAR-CISH, Rehmankhera, Lucknow, UP in 
Dashehari mango planted at a spacing of $10 \times 10 \mathrm{~m}$ with 8 treatments replicated 4 times in a Randomized Block Design for three years. The treatment details are presented in table 1. Treatments were applied within the tree basin. Proper plant protection measures were adopted for reducing the cost of pest management. Soil samples from surface and sub-surface depths $(0-30$ and 30-60 cm) were collected randomly from each of the four replicated tree basin. Foliar samples were also collected. Samples were air-dried and processed for nutrient analysis. Mango fruits were harvested; estimated the fruit yield and statistical analysis was done. Variations of Nutrient data of soils and foliar tissues were presented graphically using MS Excel.

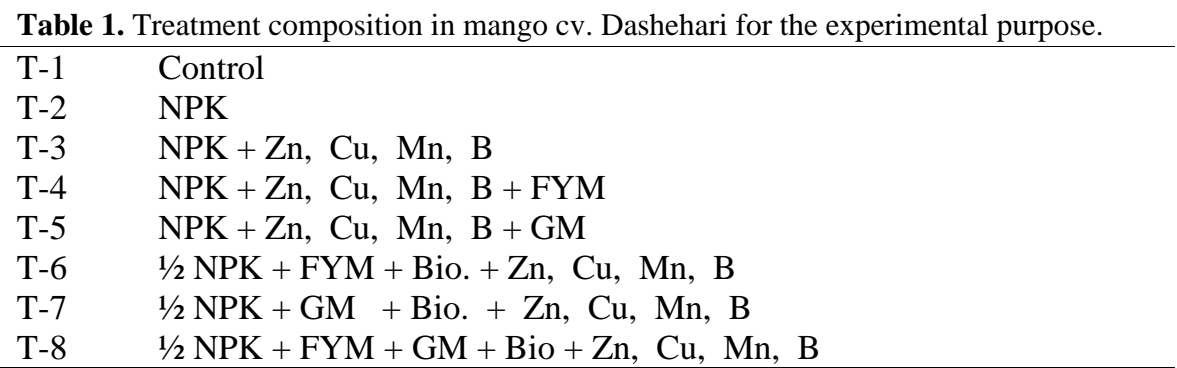

\section{RESULTS AND DISCUSSION}
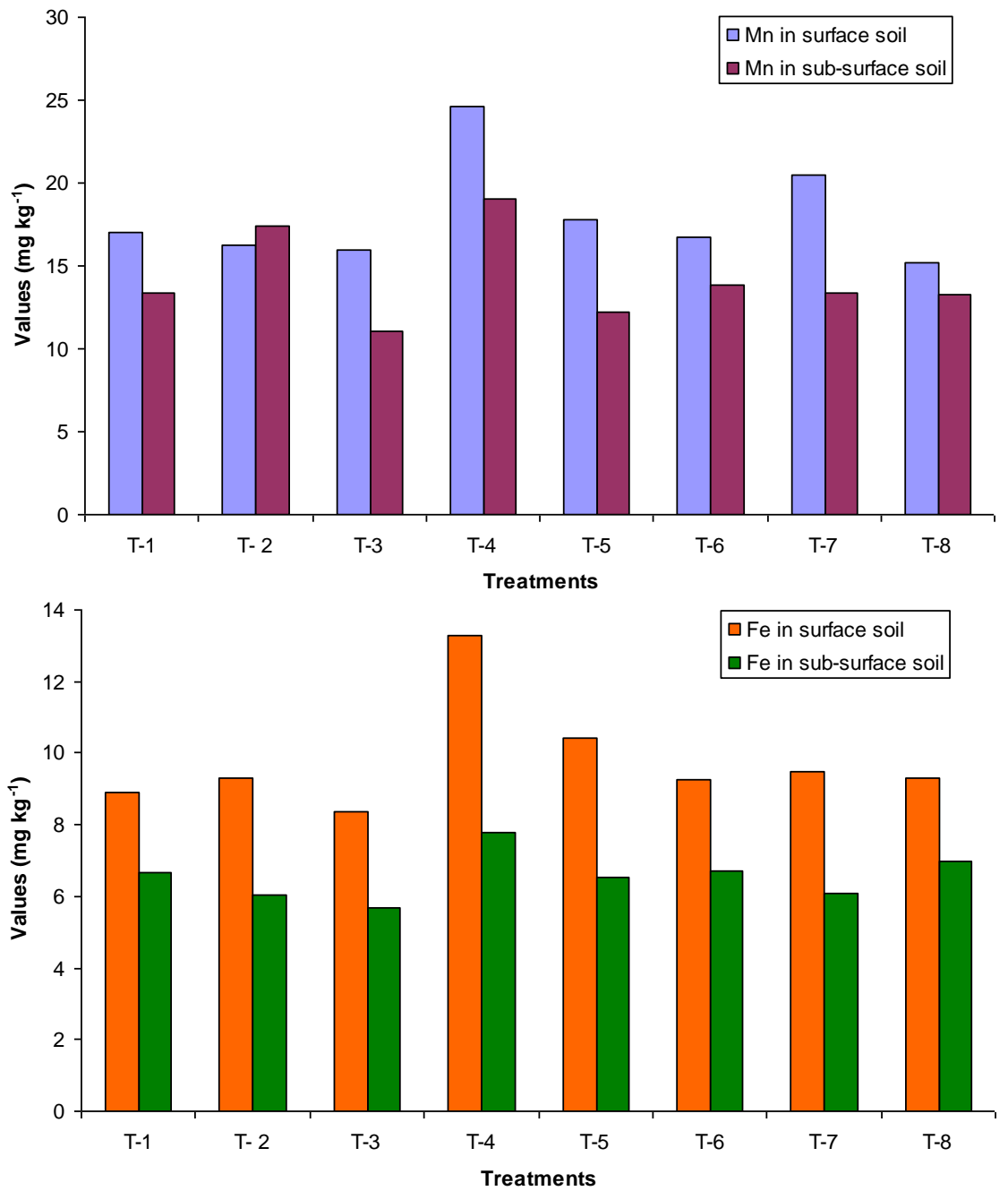

Figure 1. Effect of micronutrients and doses of fertilizers on $\mathrm{Mn}$ and Fe contents in surface and sub-surface mango orchard soils.

Both surface and sub-surface soil showed variable content of nutrients as a function of soil nutrient management system as envisaged from graphical presentation from figure 1-3. Obviously sub-surface soils had lower content than surface soil; however higher content of nutrients was recorded in the T-3, T-4 and T-8; sometimes marginally higher variations was also noted in some other treatment. Micronutrients $+\mathrm{NPK}+\mathrm{FYM}$ had higher content of $\mathrm{Mn}, \mathrm{Fe}, \mathrm{Cu}$ and $\mathrm{Zn}$ in surface and surface soils. Marginal variations across treatments in terms of soil organic carbon was noted; 0.25 to $0.55 \%$ across depths and treatments. Available $\mathrm{P}$ and $\mathrm{K}$ 
dynamics was also recorded; impact of biosources in T-7 and T-8 was higher than T-1 (Control). Fertilizer doses were reduced by half and inclusion of organic sources made nutrients more available than T1. Effect of micronutrients and doses of fertilizers on foliar nutrient contents was also revealed. Changes in its content was inferred as $1.90-1.99 \%, 0.121-0.135 \%$ and $1.10-1.25 \% \mathrm{~N}, \mathrm{P}$ and $\mathrm{K}$ respectively (Fig. 4). In case of $\mathrm{Fe}, \mathrm{Mn}, \mathrm{Cu}$ and $\mathrm{Zn}$ the corresponding values were $171.58-210.78,71.33-87.92,21.42-31.83$ and $22.33-28.92 \mathrm{mg} \mathrm{kg}^{-1}$ respectively (Fig. 5). Yield value indicated lowest in control $\left(9.08 \mathrm{t} \mathrm{ha}^{-1}\right)$ as compared to NPK $+\mathrm{Zn}, \mathrm{Cu}, \mathrm{Mn}$, $\mathrm{B}+\mathrm{FYM}\left(12.74 \mathrm{t} \mathrm{ha}^{-1}\right)$ followed by $1 / 2 \mathrm{NPK}+\mathrm{FYM}+\mathrm{GM}+\mathrm{Bio}+\mathrm{Zn}, \mathrm{Cu}, \mathrm{Mn}, \mathrm{B}\left(12.47 \mathrm{t} \mathrm{ha}^{-1}\right)$ and NPK + $\mathrm{Zn}, \mathrm{Cu}, \mathrm{Mn}, \mathrm{B}\left(11.92 \mathrm{t} \mathrm{ha}^{-1}\right.$ ) (Table 2). Harvesting good amount of fruit yield depends on a number of soil and tree factors. Among the soil factors, several physical, chemical and biological constraints of soil may hamper to produce good return; lead to harvest of low-quality mango fruit (Adak et al. 2011). Of course, sometimes seasonal variations are enough for variations in use efficiency in a mango production system (Adak et al. 2016). Thus site-specific or zone-based management options are required for better soil health management (Sharma $e t$ al. 2005, Camacho-Tamayo et al. 2013). Soil management system involving different sources and doses of nutrition always impacts on the soil properties and thus productivity (Ramesh et al. 2008, Zhang et al. 2015). Soil organic Carbon, N, K, P and micronutrients are widely influenced by the short or long term management (Malhi et al. 2011). Sometimes incorporation of green manuring also impacts soil (Mandal et al. 2003). Thus appraisals of soil properties of orchards are crucial to have an understanding of soil physico-chemical, biological properties and correlation with productivity (Kumar et al. 2012). Shukla et al. (2013) reported constrains in production to consumption chain and further sustaining the mango orchard through integrated nutrient management is obvious. Not only soil, foliar parts are also crucial to indicate the status of nutrients (Adak et al. 2018). Thus both soil and foliar assessment of nutrients indicated the orchard health status and force to ponder over to prioritize the nutrient scheduling. This management sometimes leads to better productivity and sequestration of required resources (Wani et al. 2003, Adak et al. 2015). In this experiment, inclusion of biosources along with the mineral fertilizers are thus improved the soil nutrient availability and productivity.
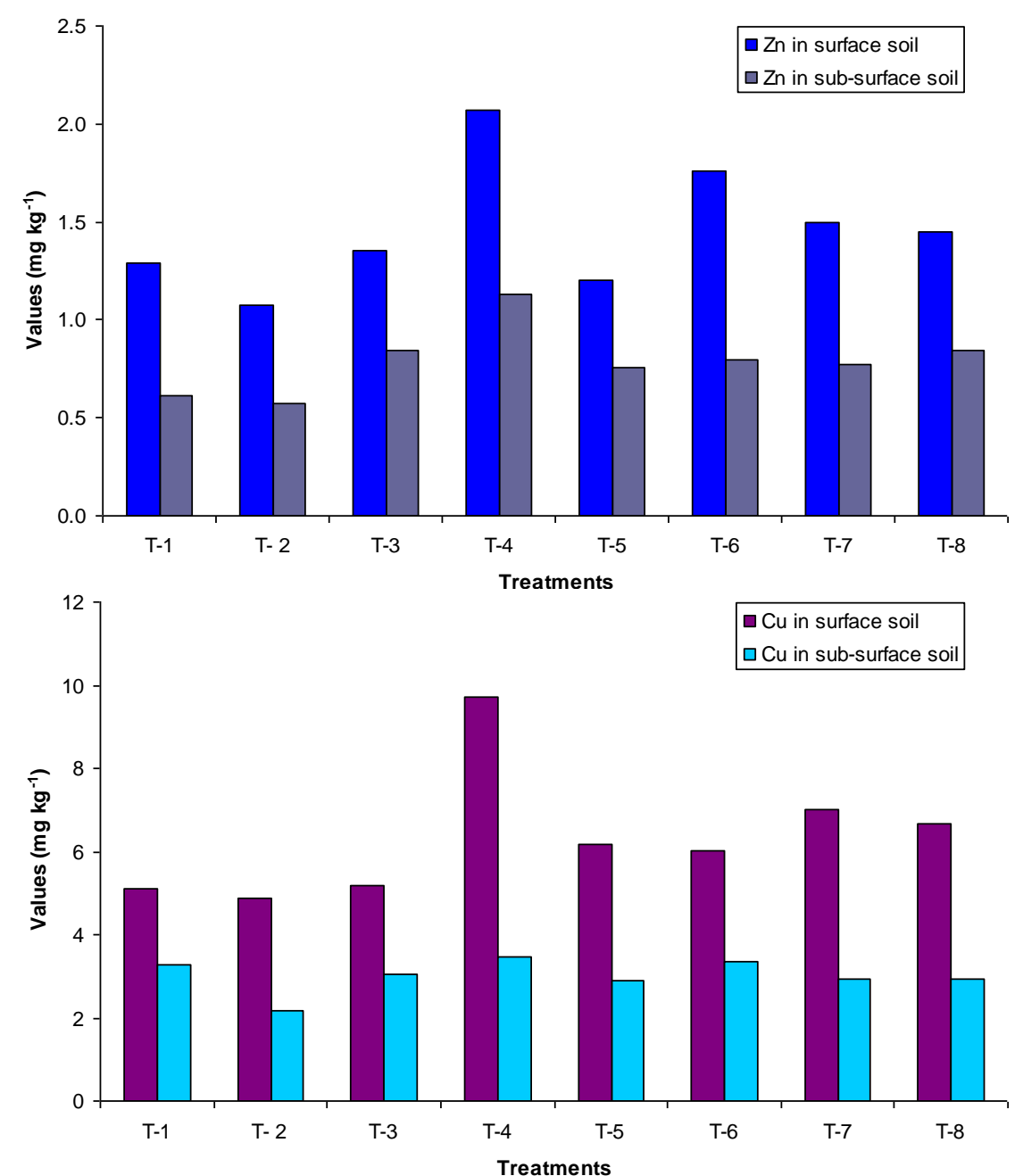

Figure 2. Effect of micronutrients and doses of fertilizers on $\mathrm{Zn}$ and $\mathrm{Cu}$ contents in surface and sub-surface mango orchard soils. 

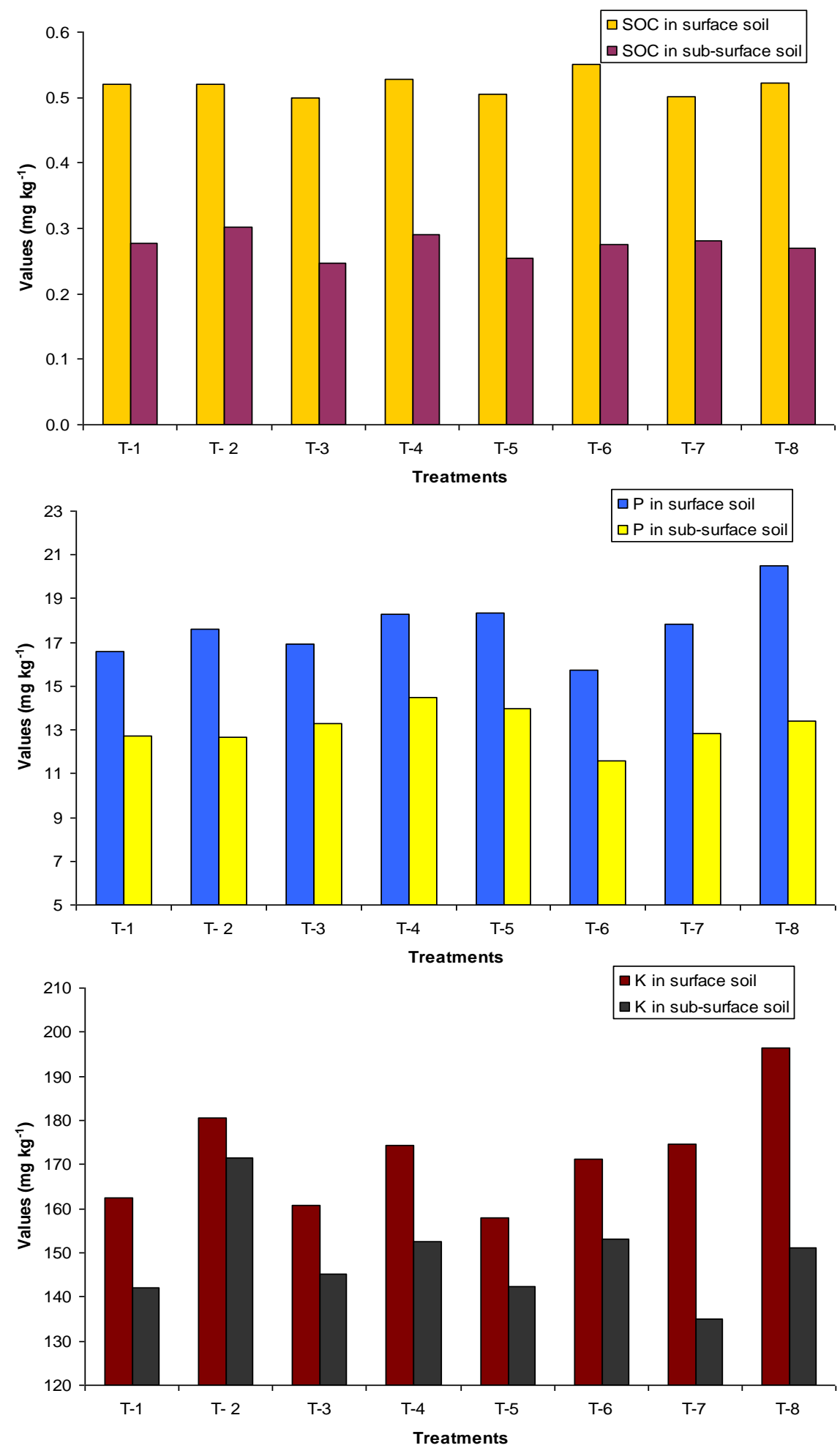

Figure 3. Effect of micronutrients and doses of fertilizers on Soil organic carbon, $\mathrm{P}$ and $\mathrm{K}$ contents in surface and subsurface mango orchard soils.

Table 2. Impact of micronutrients and doses of fertilizers on Yield in Mango cv. Dashehari

\begin{tabular}{lrrrr}
\hline Treatment & Mean Yield $\left(\mathbf{t ~ h a}^{-\mathbf{1}}\right)$ & sd & Cv (\%) & sem \\
\hline T-1 & 9.08 & 3.09 & 34.09 & 3.2 \\
T-2 & 10.79 & 0.53 & 4.92 & 0.1 \\
T-3 & 11.92 & 1.48 & 12.45 & 0.7 \\
T-4 & 12.74 & 2.85 & 22.37 & 2.7 \\
T-5 & 10.43 & 2.66 & 25.50 & 2.4 \\
T-6 & 11.11 & 4.68 & 42.11 & 7.3 \\
T-7 & 9.08 & 2.97 & 32.66 & 2.9 \\
T-8 & 12.47 & 4.40 & 35.31 & 6.5 \\
\hline
\end{tabular}



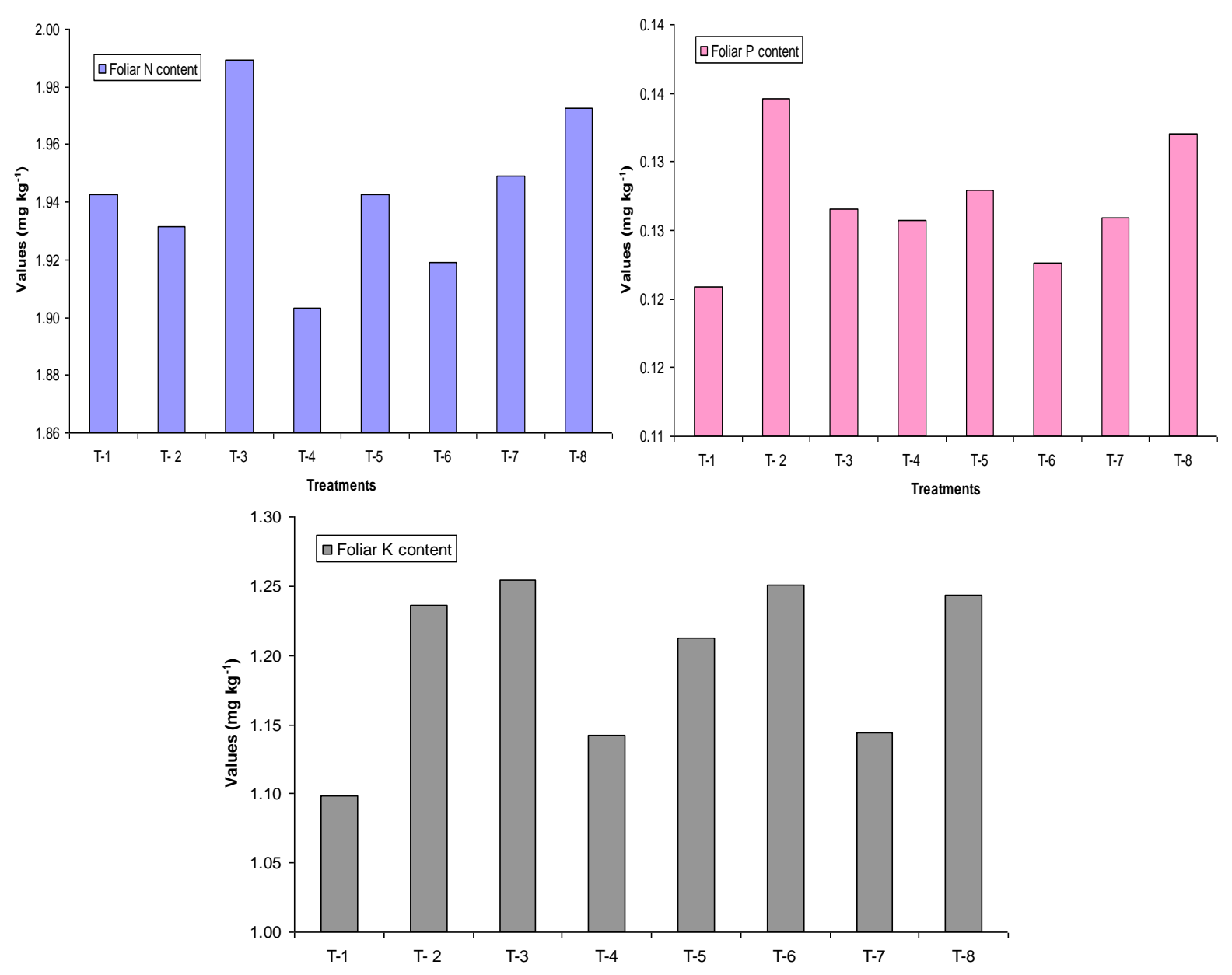

Figure 4. Effect of micronutrients and doses of fertilizers on foliar N, P and K contents in mango cv. Dashehari.
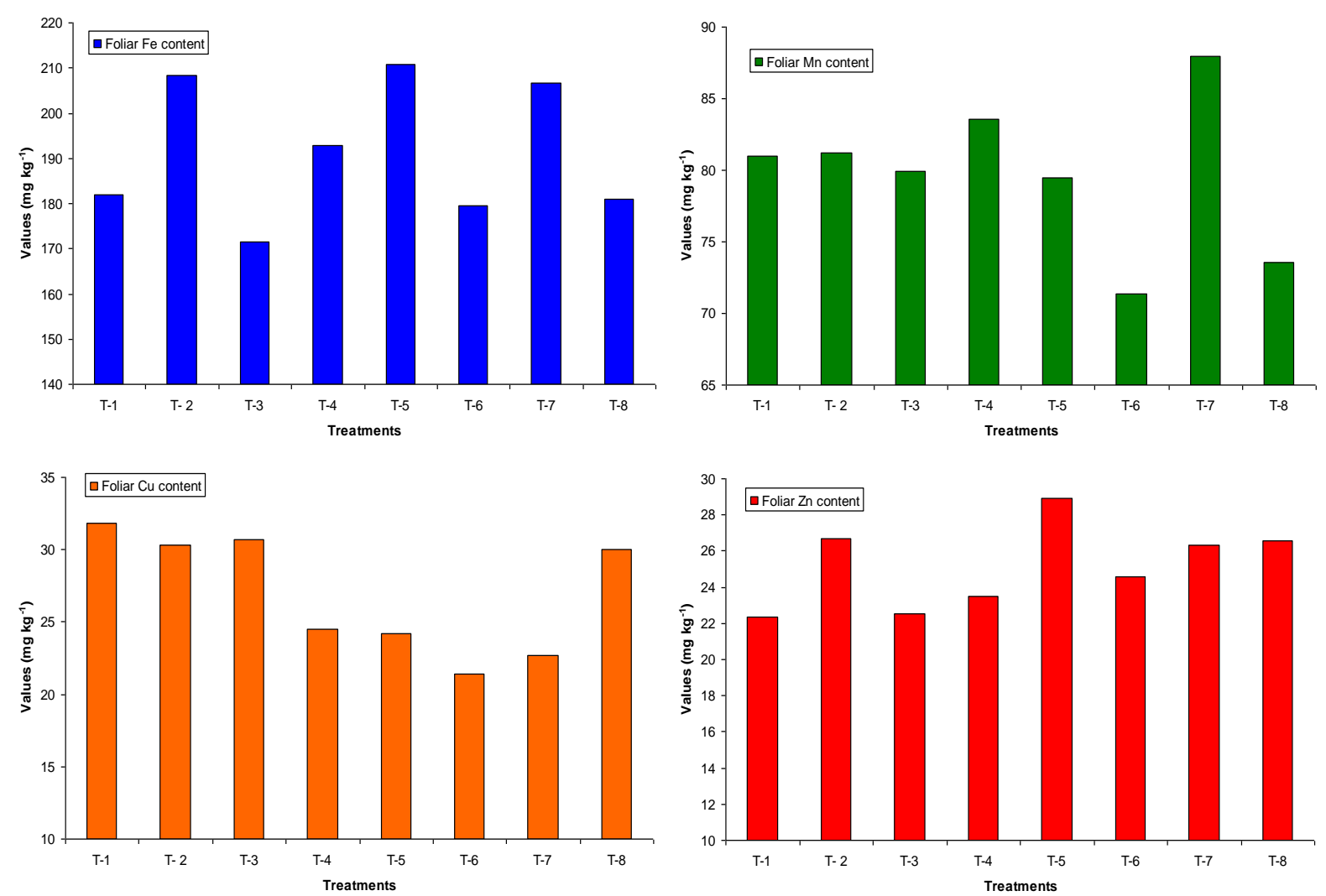

Figure 5. Effect of micronutrients and doses of fertilizers on foliar micronutrients contents $(\mathrm{Fe}, \mathrm{Mn}, \mathrm{Cu}$ and $\mathrm{Zn})$ in mango cv. Dashehari. 


\section{CONCLUSIONS}

Improvement in mango fruit yield is the success for per capita investment made by the farmers. Mango growers eagerly waited for over one year to harvest quality fruits so that a good amount of profit could be obtained from their orchard. For increasing yield from per unit area, adoption of integrated nutrient management at farmers' field is required. The generosity with which farmers are involved in mango production determines the total yield harvested from each of the orchards. In this regard, inclusion of micronutrients, biosources, chemical fertilizers and their different combinations may help farmers to realize the dream yield. The present study was thus concluded that micronutrient + FYM + NPK or micronutrient + NPK or micronutrient $+1 / 2$ NPK + FYM + Green manuring + Biofertilizer could lead to harvests of 11.92 to $12.74 \mathrm{tha}^{-1}$ mango fruit as compared to $9.08 \mathrm{t} \mathrm{ha}^{-1}$ from the control plot. These combinations should be tried at farmers' field for their benefit to harvest greater yield.

\section{ACKNOWLEDGMENTS}

Director, ICAR-CISH, Lucknow, UP, India is duly acknowledged for providing assistance and financial support. Co-operation from other colleagues is also duly acknowledged.

\section{REFERENCES}

Adak T, Pandey G, Singh VK \& Rajan S (2019) Assessing soil nutrient index in mango orchards of Maal area, Lucknow, U.P. Journal of Soil and Water Conservation 18(3): 263-267.

Adak T, Kumar K \& Singh VK (2015) Spatial variations of soil physical parameters and organic carbon stock under high density mango orchard ecosystem. In: Bhan S \& Arora S (eds) Advances in Soil and Water Resource Management for Food and Livelihood Security in Changing Climate. Soil Conservation Society of India, New Delhi, pp. 163-178.

Adak T, Kumar K \& Singh VK (2016) An Appraisal of Seasonal Variations in Thermal Indices, Heat and Water Use Efficiency in Mango. In: Rao RK, Sharma PK, Jirli B \& Raghuraman M (eds) Climate change and its implications on Crop production and food security. Mahima Research Foundation and Social Welfare, Banaras Hindu University, Varanasi, pp. 183-188. [ISBN: 978-81-926935-4-5]

Adak T, Kumar K, Shukla SK, Singh VK \& Rajan S (2018) Micronutrient status in leaf tissue of mango germplasm conserved under subtropical environment of Lucknow, Uttar Pradesh, India. Tropical Plant Research 5(1): 96-106.

Adak T, Singh, VK \& Kumar K (2011) Identifying some soil physical constraints in sustaining mango productivity in Malihabad region of Uttar Pradesh. In: $X^{\text {th }}$ Agricultural Science Congress on Soil, Plant and Animal Health for enhanced and sustained agricultural productivity. NBFGR (10-12 February 2011), Lucknow, pp. 23.

Camacho-Tamayo JH, Sanabria YR \& Santana LM (2013) Management units based on the physical properties of an Oxisol. Journal of Soil Science and Plant Nutrition 13(4): 767-785.

Kumar K, Adak T \& Singh VK (2017) Green manuring and nutrient management impacting soil properties and sustainability of mango orchard. Journal of Soil and Water Conservation 16(1): 72-78.

Kumar K, Adak T, Singha A, Shukla SK \& Singh VK (2012) Appraisal of soil fertility, leaf nutrient concentration and yield of mango (Mangifera indica L.) at Malihabad region, Uttar Pradesh. Current Advances in Agricultural Sciences 4(1): 13-19.

Malhi SS, Nyborg M, Solberg ED, McConkey B, Dyck M \& Puurveen D (2011) Long-term straw management and $\mathrm{N}$ fertilizer rate effects on quantity and quality of organic $\mathrm{C}$ and $\mathrm{N}$ and some chemical properties in two contrasting soils in Western Canada. Biology and Fertility of Soils 47: 785-800.

Mandal UK, Singh G, Victor US \& Sharma KL (2003) Green manuring: its effect on soil properties and crop growth under rice-/wheat cropping system. European Journal of Agronomy 19: 225-237.

Ramesh V, Korwar GR, Mandal UK, Prasad JVNS, Sharma KL, Ramakrishna YS \& Venkanna K (2008) Influence of fly ash mixtures on early tree growth and physicochemical properties of soil in semi-arid tropical Alfisols. Agroforestry Systems 73: 13-22.

Sharma KL, Mandal UK, Srinivas K, Vittal KPR, Mandal B, Grace JK \& Ramesh V (2005) Long term soil management effects on crop yields and soil quality in dryland Alfisols. Soil and Tillage Research 83: 246259.

Shukla SK, Mishra D, Adak T \& Kumar K (2013) Constraints in production to consumption chain of mango in Malihabad, Lucknow, Uttar Pradesh. Current Advances in Agricultural Sciences 5(1): 87-91. 
Wani SP, Pathak P, Jangawad LS, Eswaran H \& Singh P (2003) Improved management of Vertisols in the semiarid tropics for increased productivity and soil carbon sequestration. Soil Use and Management 19: 217-222.

Zhang S, Li H, Yang X \& Sun B (2015) Effects of soil management regimes on biochemical properties of a loess soil. Journal of Soil Science and Plant Nutrition 15(3): 711-725. 